\title{
Virtual space used in the communication activities of local governments on the example provided by the communes of the Upper Silesia and Zagłębie Metropolis
}

\author{
Przestrzeń wirtualna wykorzystywana \\ w działaniach komunikacyjnych samorządów \\ na przykładzie gmin Górnego Śląska i Zagłębia
}

\author{
Dariusz Krawczyk*
}

\begin{abstract}
The aim of the paper is to identify the scope of social media application in communication activities of local governments. The research field is a statutorily separated metropolitan area in the Silesia Province, established from 41 communes. The applied research methods included the analysis of the Internet sources and the academic literature. The conclusions were obtained concerning the activity of local government units in social media, contributing to the organization of the state of knowledge on the objectives, expenditure
\end{abstract}

\begin{abstract}
Abstrakt
Celem artykułu jest określenie zakresu wykorzystania mediów społecznościowych w działaniach komunikacyjnych samorządów. Przedmiotem badań jest wyodrębniony statutowo obszar metropolitalny województwa śląskiego, składający się z 41 gmin. Zastosowane metody badawcze obejmowały analizę Internetu, źródeł internetowych oraz literatury przedmiotu. Stąd wyciągnięto wnioski dotyczące działalności jednostek samorządu terytorialnego w sferze mediów społecznościowych, przyczyniając się do uporządkowania stanu
\end{abstract}

* Expert witness in the field of social communication and management, (d.krawczyk@, olpress.pl); iD https://orcid.org/0000-0003-1823-0309. 
and effects of local administration activities in the studied part of cyberspace.

Key words: municipality, information policy, Facebook, promotion, digital accessibility wiedzy w odniesieniu do celów, wydatków i efektów działań administracji samorządowej w badanej części cyberprzestrzeni.

Słowa klucze: gmina miejska, polityka informacyjna, Facebook, reklama, dostępność cyfrowa

\section{Introduction}

The reactivation of territorial self-government in Poland initiated a public debate on the legitimacy and form of publishing activities of local administration. The dispute about the communes' participation in the functioning of the press market has been going on for three decades, and the subject still raises much controversy. The respondents emphasize, e.g., spending public funds on promoting local decision makers, unfair competition against commercial periodicals, threat to freedom of speech. On the other hand, the need to conduct an information policy in order to integrate and activate the local community or the necessity to carry out the commune's own tasks (e.g., promotion) is indicated. Apart from their involvement in the sphere of traditional media, local governments are also important entities operating in a virtual environment, where, in addition to their own communication activities, they also perform statutory duties, e.g., in the field of access to public information. The changes in the contact formula between local government units and the social environment make the use of tools based on the cyber resources increasingly common. Furthermore, it does not only refer to the authorities or the institutionalized so-called commune support apparatus. Currently, "Facebook or YouTube type portals are becoming channels of media content distribution, in which information duties of the office intersect with promotional or self-presentation functions of commune authorities. This raises both doubts about the responsibility for the content published in the municipal online media as well as about the compliance of the citizens' constitutional and statutory rights to information with the rules of social networking sites regarding freedom of expression and the use of profile data for advertising purposes.'(Kowalik, 2018: 446) Taking into account the widespread use of Facebook by local government units in maintaining communication relations with residents, a study was conducted on the form and effects of using this service. 


\section{Research on communication activity of local administration with the use of social media}

An analysis of Internet sources was carried out in order to obtain up-to-date information on the use of Facebook in the communication activities of municipalities. The study covered local government units, which form the first legally distinct metropolitan area in Poland (Journal of Laws of 2017, item 730), in the Silesia Province.

The Upper Silesian - Zagłębie Metropolis (GZM) was established on January 1, 2018 in the area of about 2.55 thousand square kilometers, which was inhabited by about 2.3 million people ${ }^{1}$ who were residents of 41 communes.

The research procedure determined the need to identify the Facebook official profile of the local government unit that is part of the GZM, determine the number of users, determine the number of published posts in the unit of time, and verify the number of communication interactions. The data obtained were compared with the number of inhabitants in order to gain knowledge about the social scope and communication range of local administration using social media, as well as the amount of expenditure on promotion incurred in consecutive years by the surveyed local governments to determine the role of these activities for decision makers.

At the beginning, it should be stated that in 2018, when collecting data for analysis, in the national surveys on the presence of local government administration on Facebook, it was established that "in the case of cities, 96.99\% of offices have Facebook accounts"(Romanowski, Szymkowiak, 2018: 453). Such a high level of social media use in maintaining contact with recipients on a national scale justified the formulation of a statement that they are commonly used by local governments.

Social media should be an important element in the communication activities of local government units as a source of information and advertising content as well as a tool for feedback communication,. Therefore, one of the research questions formulated in 2019 was whether small communes aspire to the indicated standard. For this reason, it was necessary to determine the percentage of communes using Facebook in the entire statutory metropolitan area of the Upper Silesian conurbation.

${ }^{1}$ In 2018, the Upper Silesian-Zagłębie Metropolis was comprised of: Będzin, Bieruń, Bobrowniki, Bojszowy, Bytom, Chełm Śląski, Chorzów, Czeladź, Dąbrowa Górnicza, Gierałtowice, Gliwice, Imielin, Katowice, Knurów, Kobiór, Lędziny, Łaziska Górne, Mierzęcice, Mikołów, Mysłowice, Ożarowice, Piekary Śląskie, Pilchowice, Psary, Pyskowice, Radzionków, Ruda Śląska, Rudziniec, Siemianowice Śląskie, Siewierz, Sławków, Sosnowiec, Sośnicowice, Świerklaniec, Świętochłowice, Tarnowskie Góry, Tychy, Wojkowice, Wyry, Zabrze, Zbrosławice. 
It turned out that in the research field composed not only of cities but also smaller towns, the ratio of communes conducting communication activities using the official Facebook profile is $87.8 \%$. Each city-district used social media, and all local government units which at the time of the survey did not use such a communication tool (i.e., about $12 \%$ of towns and cities within the area of GZM) actually belonged to the group of small communes whose number of inhabitants ranged from 4.8 thousand to slightly more than 9 thousand people.

\subsection{Form of content management and social scope of self-government profiles}

A study of the scale of communication activity using official Facebook accounts was carried out to illustrate the level of social media use in the implementation of the information and promotion policy of local government units. The analysis covered the social scope of profiles documented by the number of so-called likes, the number of posts published within seven consecutive days ${ }^{2}$ and the number of users' reactions.

The obtained results show quite obvious conclusion that the largest social reach in absolute numbers is achieved by large cities (particularly city-districts), which have at their disposal adequate funds, organizational and logistic potential, and human resources. They include Katowice as well as Bytom, Chorzów, Dąbrowa Górnicza, Ruda Śląska, Sosnowiec, Tarnowskie Góry, Tychy, and Zabrze.

People responsible for running Facebook profiles of particular communities showed varied activity, measured by the number of disseminated posts, which probably resulted from the implementation of individually adopted communication strategy assumptions. Some broadcasters, through the daily provision of an "information and promotion package" consisting of numerous messages, implemented a model of adapting a communication tool such as Facebook to the tasks of a medium equivalent to traditional media. To a certain extent, they even mapped the role of local agency services, publishing many posts every day. The intensification of information activities understood in this way was observed, among others, in the case of profiles of Bieruń, Dąbrowa Górnicza, Mysłowice, Tarnowskie Góry or Zabrze, ${ }^{3}$ where local governments' social media could be

2 The author's own research was carried out from 3 to 10 October 2019, using official Facebook profiles of the communes forming the Upper Silesian - Zagłębie Metropolis.

3 The broadcasters in these municipalities made between 26 and 31 posts per week available on FB profiles. 
a source of event announcements for journalists, at the same time fulfilling the function of media relations modules. On average, for the entire metropolitan area, it can be assumed that the communes published about 11 posts per week, ${ }^{4}$ although broadcasters were reported to transmit both a considerably lower and a significantly higher number of messages. The average number of responses to each post was about 32 for the surveyed communities, but in some cases they were considerably larger due to the competitions for Internet users, which took place during the analysis and required interaction.

What is important, the survey allowed to determine the level of reaching stakeholder groups of local government units, i.e., inhabitants deciding on the composition of municipality authorities in elections, which is important, and even the most important from the standpoint of broadcasters' communication activities (Journal of Laws of 1990 No. 16, item 95). Through Facebook, the largest - in the percentage terms - reach of recipients in relation to the number of people living in a given commune was more often achieved by small towns than by city-districts. Apart from the capital of the region, i.e., Katowice, which maintains its leading position in each of the categories, a comparison of the social range of the profile in relation to the number of inhabitants indicates the leading position of such communes as Bobrowniki, Pyskowice, Radzionków, Świerklaniec, Wojkowice or Wyry.

The analysis showed that the total social reach of Facebook profiles managed directly by local governments covers only $16.5 \%$ of the population living in the analyzed area. Of course, when formulating conclusions concerning the communication effectiveness of social media, one should take into account the criterion of interaction between accounts administered by other broadcasters who are dependent on or affiliated with local government units. Apart from the profile of the commune, the citizens are also addressed by the broadcasts distributed by cultural institutions, commune companies or companies with commune capital participation, sports facilities, entities conducting recreational activities, commune health care institutions, and other units providing services to the residents for or under the authority of the local government. The multiplication of content sources, which are disseminated, may result in the phenomenon of communication synergy.

It is also worth including in this description personal profiles of single-person commune authorities (i.e., commune heads, mayors or presidents) and individuals involved in local governance. Formally, the social media notion of local governments cannot be used in this case, but the thematic orientation of the content disseminated by this method of distribution will not contradict the official media program line of local administration. Furthermore, the inclusion of personal ac-

${ }^{4}$ The study covered the profiles of GZM local government units from 3 to 10 October 2019. 
counts of local politicians or local government activists in the information policy may ensure that the social reach of the public content will be broadened.

\subsection{Expenditure on promotion of the commune in relation to social media activities}

In accordance with the classification of budget expenditure, the budget expenditure reported by the GZM communes was also examined. The budget expenditure included in section 750 - "public administration," chapter 75075 - "promotion of territorial self-government units" in the subsequent years from 2016 to 2018.

While analyzing the amount of public funds spent on promotion of local government units, it was found that $41.4 \%$ of municipalities in the metropolitan area were systematically increasing their expenditure. A consistent annual reduction of funds allocated to promotion was noted in the case of $14.6 \%$ of communes. However, fluctuations in the level of outlays in subsequent years were revealed in the budgets of $43.9 \%$ of communes. These values illustrate the importance of promotional activities in development strategies of local government units. At the same time, they show that the role of shaping the assumed image of a commune through persuasive communication, implemented by means of various marketing and advertising tools, is very important for the majority of the surveyed local governments. Such a conclusion can be reached considering not so high percentage of communes that constantly increase their expenditure on promotion, but first of all, a relatively small number of local government units that reduce this expenditure (less than 15\%). Fluctuations in the scale of funds in subsequent years justify, among others, differences in income or an increase in burdens related to tasks delegated to their implementation without allocating appropriate funds.

However, when comparing the obtained results with the effectiveness of communication activities via Facebook, measured by the social reach of the selfgovernment profile, it turned out that the total amount of funds allocated to the promotion of localities is practically irrelevant. In the group of communes which successfully use social media in contacts with inhabitants and gain the highest social reach, ${ }^{5}$ about $35 \%$ of them constantly increase their promotional budgets and $33 \%$ regularly decrease them.

5 The list includes municipalities with a social coverage of about $20 \%$ and more (including broadcasters with $19.3 \%$ and $19.8 \%$ coverage). 
The survey also revealed that some communes dedicate their presence in social media to separate legal regulations. For example, "In order to determine the rules and conditions of using the official municipal fanpage of the Municipality of Sośnicowice on the social networking site Facebook," the Mayor's regulation (Ordinance No. 19/2018) issued the "Internal Regulations." The document specifies the rules of using the commune profile on Facebook, stating that the fanpage "is a place to discuss and exchange opinions on the commune of Sośnicowice, activities undertaken by the Municipal Office in Sośnicowice, and organizational units of the commune," while stating that it does not constitute "an official way of communication with the Municipal Office in Sośnicowice." Interestingly, the regulations sanctioned the freedom to present opinions and express opinions by emphasizing: "the fanpage of the Municipality of Sośnicowice is allowed to post any comments on the activities of the Municipality, including critical ones." By the decision of the mayor, it was forbidden to publish entries incompatible with the law and good manners, as well as "materials of advertising or promotional character of companies or brands without the prior consent of the Moderator." This should be understood as allowing to publish advertising content after obtaining appropriate approval. It seems that in this way, the possibility of raising funds from potential advertisers interested in publishing paid advertisements on the local government's Facebook profile has been opened.

\section{The development directions of communication activities by local governments in a virtual environment}

The authors of the study on the use of media in local government communication, which was completed in 2015, stated that "the multitude of tasks imposed on local authorities by both legislators and NGOs, as well as the diversity of stakeholders, force managers to use various forms and contents of the message. Social media, by their very nature, offer a wide range of possibilities for adapting the message to the requirements of particular groups." (Szymkowiak, Scheibe, 2016: 309). At the same time, they distinguished the criteria for dividing information published on Facebook taking into account: recipients (individual and institutional), stakeholder groups (local community, tourists, investors/entrepreneurs), time of described events (past, current, future), news and significance of information (urgent and important for the recipient, general), nature of information (information, image) and scope of information (institutional, spatial). There are still many areas that can be appropriated by electronic content carriers of 
the local government. For example, the transmission of decisions, resolutions or other types of official correspondence to the residents is still carried out primarily by traditional mail or by delivery service providers employed by the local administration. At present, such a solution seems to be more effective than publication of announcements by local government websites or social media, which are not perceived by recipients as a carrier of "official" content. But actually, now a hybrid method of interaction may be considered in some cases, "in which the office informs the residents about the decision with a short justification, and detailed comments are posted on the decision-maker's website. Such a method, supported by sending an e-mail and information in local television, radio and the press, is very effective" (Balicki, Dryja, Korłub, Tyszka, 2017: 165). The use of websites and mobile applications of local government units in contacts with the social environment can also be increased in this way. Moreover, social media have a constantly growing potential that can be used by local government units not only in the sphere of information policy, but also in the implementation of the concept that smart cities should fulfill. It should be remembered, however, that "all currently applied innovative solutions in public administration, not only in the area of city management or smart cities, are a huge challenge in the context of local lawmaking, but also in the area of creating legal acts regulating the issue of new technologies" (Kidyba, Makowski, 2017: 70). In this context, it is worth mentioning the legislative conditions, including those enforcing the digital availability of Internet presentations and mobile applications.

\section{Legislative standards for digital accessibility of public sector entities}

Technological development makes it necessary for public sector entities to face challenges connected with modern forms of communication. These include, among others, making mobile applications available. In linguistic terms, these are "computer-aided applications" that are intended for mobile devices such as smartphones and tablets. The Polish public administration at the central level offers numerous applications such as "mObywatel," "KNF Alert," "Granica,"

${ }^{6}$ Definition behind the Internet version of the PWN Dictionary of Polish Language at https://sjp.pwn.pl [accessed 1 October 2019].

7 Allows to activate and use „mDocuments” via smartphone.

8 The application enables, among others, access to entries on the list of public warnings of the Polish Financial Supervision Authority.

${ }^{9}$ It also provides up-to-date information on the situation at border crossings through a smartwatch or watch in six languages. Status as of October 2019. 
“Geoportal Mobile,"10 "Regionalny System Ostrzegania,"11 “Jakość powietrza w Polsce." ${ }^{\prime 2}$ Individually developed communication tools, based on the use of the potential of cyberspace, are also being used more and more commonly by local governments, enabling access to various types of data, and also promoting their tourist attractions, investment offers, activities in the field of municipal economy, cultural events or recreational undertakings. The communication activity of local government units in the virtual environment is not subject to restrictions due to the assessment of its legitimacy, effectiveness or incurred costs. However, it should be based on technical criteria and recommendations enabling wider access to disseminated content, minimizing the risk of exclusion due to the age or disability of users. Thus, online information strategies, as well as eGovernment activities, must take into account the standards of existing legislation. In this context, it should be recalled that the European Parliament and the Council of the European Union in 2016 adopted a directive [Directive (EU) 2016/2102 of the European Parliament and the Council dated 26 October 2016 on the accessibility of websites and mobile applications of public sector bodies (OJ EU L 327/9 of 2 December 2016)] on websites and mobile applications managed by public sector bodies stating, inter alia, that these bodies "increasingly use the internet to develop, collect and provide a wide range of information and online services of fundamental importance for society," which should be "more accessible to users, especially disabled people," and this is to be guaranteed "on the basis of common accessibility requirements" aimed at ensuring that services can be used regardless of the users' abilities, age, equipment or software. Interestingly, the document also gave a definition of mobile apps, since according to the directive, "a mobile app means application software designed and developed by or on behalf of public sector bodies for use by the general public on mobile devices - such as smartphones and tablets. It does not cover software that controls these devices (mobile operating systems) or the hardware itself."13

The implementation of the Directive into the Polish legal system was preceded by consultations, during which attention was also drawn to the definition of mobile applications. It was stressed that, among others, "an application downloaded from the Internet and running on a mobile device is subject to the $\mathrm{WCAG}^{14}$ guideline if it exchanges information with the network. An application downloaded from the

${ }^{10}$ Access to spatial data provided by the Central Office of Geodesy and Cartography.

${ }^{11}$ Emergency warnings on meteorology, hydrology, road events, etc.

${ }_{12}$ Information of the Chief Inspectorate of Environmental Protection on air pollution concentrations.

${ }_{13}$ Article 3, point 2. of Directive (EU) 2016/2102 of the European Parliament and the Council dated 26 October 2016.

14 The Web Content Accessibility Guidelines, a set of recommendations for the creation of websites that take into account the needs, expectations and capabilities of people with disabilities, has been included in WCAG version 2.0 as the international standard ISO/IEC 40500:2012 since 2012 . 
web and launched offline is no longer, web content' and as such is not subject to the WCAG guideline. This was also the case for desktop applications" (Opinion of the Visible Foundation). It referred to the guidelines aimed at improving the accessibility for people with disabilities, which had already been introduced by the Interoperability Law (Journal of Laws of 2017, item 2247) that explicitly required public authorities to present information resources in order to ensure that ICT systems comply with the "Web Content Accessibility Guidelines (WCAG 2.0)." The regulation announced on May 16, 2012 defined the National Interoperability Framework, i.e., the ways of proceeding in the area of ICT systems to ensure, among others, the availability of electronic services, improvement of their effectiveness, rationalization of costs and more effective customer service. Using the concept of interoperability at the organizational ${ }^{15}$, semantic ${ }^{16}$ and technological ${ }^{17}$ levels, the standards and procedures in this area are indicated. The National Interoperability Frameworks, as specified in the regulations, have been composed of: (1) the ways of achieving interoperability, (2) the architecture of ICT systems of entities performing public tasks, and (3) the interoperability repository on ePUAP, ${ }^{18}$ i.e., a nationwide ICT platform enabling citizens to communicate with public entities. It should be noted that under the regulation (Journal of Laws of 2017, item 2247), interoperability has been achieved through standardization, ${ }^{19}$ interchangeability ${ }^{20}$ or compatibility. ${ }^{21}$

15 According to the regulations, ,operational interoperability” refers, among others, to the formula of informing by entities performing public tasks about the way of accessing and using the services, standardization and unification of procedures, taking into account the need to ensure proper cooperation of these entities or publishing and updating in the Public Information Bulletin the descriptions of procedures applicable to the electronic handling of matters.

16 The semantic level of interoperability as indicated in the regulation is achieved, inter alia, through the appropriate use of data structures and the meaning of the data contained in those structures and their proper publication in the interoperability repository, and the use in the registers of references to registers containing reference data to the extent necessary to carry out the tasks.

17 ,Technological interoperability' under the quoted regulation requires the application of minimum requirements for ICT systems and regulations contained in separate regulations, and in the absence of specific regulations indicates the need to take into account the provisions of relevant Polish Standards, international standards or standards recognized by international organizations as good practice.

${ }_{18}$ Electronic Platform for Public Administration Services (ePUAP) ,provides citizens and businesses access to electronic communication services with public administration. Thanks to the ePUAP, public administration entities and other entities performing public tasks can make their services available free of charge in electronic form, they do not have to build their own IT system". Source: Department of the Ministry of Digitization in the Internet Service of the Republic of Poland at https://www.gov.pl [accessed 22 October 2019].

19 The codification is understood as: , the application of compatible standards, norms and procedures by various bodies carrying out public tasks'.

${ }^{20}$ Interchangeability is: ,the ability to replace a product, process or service without disrupting information exchange' while, meeting all requirements'.

${ }^{21}$ Compatibility is: ,suitability of products, processes or services intended for shared use' for ,meeting essential requirements' and assuming ,no adverse effects'. 
Finally, the law announced on May 8, 2019, implementing the principles of the EU directive, defined a mobile application as " publicly available software with a touch interface designed for use on portable electronic devices, excluding applications intended for use on portable personal computers" (Journal of Laws of 2018, item 848). The digital accessibility of a website and a mobile application described in the act is based on ensuring its functionality, compatibility, visibility and comprehensibility (Journal of Laws of 2018, item 848). The legislator has clarified the concept of functionality used as properties that enable the user to take advantage of all the functions offered by websites or mobile applications. Compatibility, within the meaning of the cited act, is a feature that allows cooperation with as many programs as possible, but with the emphasis on the fact that this group includes tools and programs that support people with disabilities. The property that allows a user to use a mobile application or a website by hearing, sight or touch is, in turn, perceivability. The last criterion of digital accessibility is comprehensibility, i.e., the ability to make the recipient aware of the content meaning and to identify the way it is presented.

In accordance with the act in question (Journal of Laws of 2018, item 848), the public entity is to ensure digital accessibility: the subjective website of the Public Information Bulletin and the following elements and functions of the website or mobile application: (a) contact details (as well as a link to the subject side of the BIP of this institution, if under separate provisions it is obliged to run it), (b) tools for contact with the public entity, (c) navigation, (d) the so-called "declaration of availability," (e) information concerning a crisis situation and public security, (f) official documents, templates of contracts, and other documents intended for incurring civil law obligations. However, the act obliges public institutions to conduct communication activities ensuring digital accessibility of websites or mobile applications, provided that this does not involve ",excessive costs." The signaled technological, logistic and formal conditions should be taken into account by the communication services of local government units already at the stage of designing communication activities carried out with the use of tools such as a website or a mobile application.

\section{Conclusions}

The research described above confirmed that social media are commonly used by local government units, although smaller municipalities still ignore the existence of social media in their information policy. However, more and more often, small towns and cities use Facebook's potential more effectively than large cities in terms of developing a certain percentage of social coverage in relation 
to the total population. Moreover, the communication activity is also a source of messages from separate entities or characters acting for the benefit of local administration. From the broadcasters' point of view, the process is beneficial, but for the recipients it may mean isolation from information which is incompatible with the local government's program line.

Municipalities, when focusing on social media, should take into account the fact that they constitute a highly individualized communication tool. As a consequence, a user identified on a local government profile usually means no more than one person remaining within the commune's communication activities. All the more so because Internet identities are often multiplied, which means further lowering the real social range of social media. The situation is different in the traditional press market, where there is a phenomenon of shared readership of periodicals offered to the recipients (more often in the case of copy sales, but also in the free distribution network). However, unlike the increasingly popular online media, the conventional printed press is perceived as an archaic tool. At the same time, it requires constant and often high financial outlays on activities not directly related to the preparation of content dedicated to recipients, such as printing services or distribution.

According to the research completed in $2018,{ }^{22}$ the content disseminated by the local community in social media was categorized by the author as "announcing" posts (encouraging participation in interesting events), "informative" (local government news), "provocative" (persuasive content ",encouraging online action for a town or event") and "participative" (community activating).

After the analysis, it came to light at the end of the study that the provocative posts "already constituted the vast majority as a category and dominated the reactions of profile users. The moderator of the official profile, seeing a significant increase in the number of posts, comments and accesses, was somewhat encouraged to prefer these types of posts. The message was therefore profiled as «distribution of emotions»" (Kowalik, 2018: 23). This is a great opportunity for the local government to activate the residents, but also a potential weakness of social media due to the possibility of communication abuse.

Thus, websites and mobile applications, as well as social media managed by the local government, can contribute to the effective dissemination of information, integration of local communities, implementation of innovations and increase the level of civic participation. However, they are not an area free from the dangers of manipulating information, giving messages containing persuasive messages or even disseminating the fake news.

22 The study by Krzysztof Kowalik from the University of Warsaw, combining quantitative and qualitative analysis was carried out, in two periods: in February 2017 and February 2018', in the first stage observing 66 cities with district rights. 
Determination of the trend in the municipality's budget expenditure on promotion.

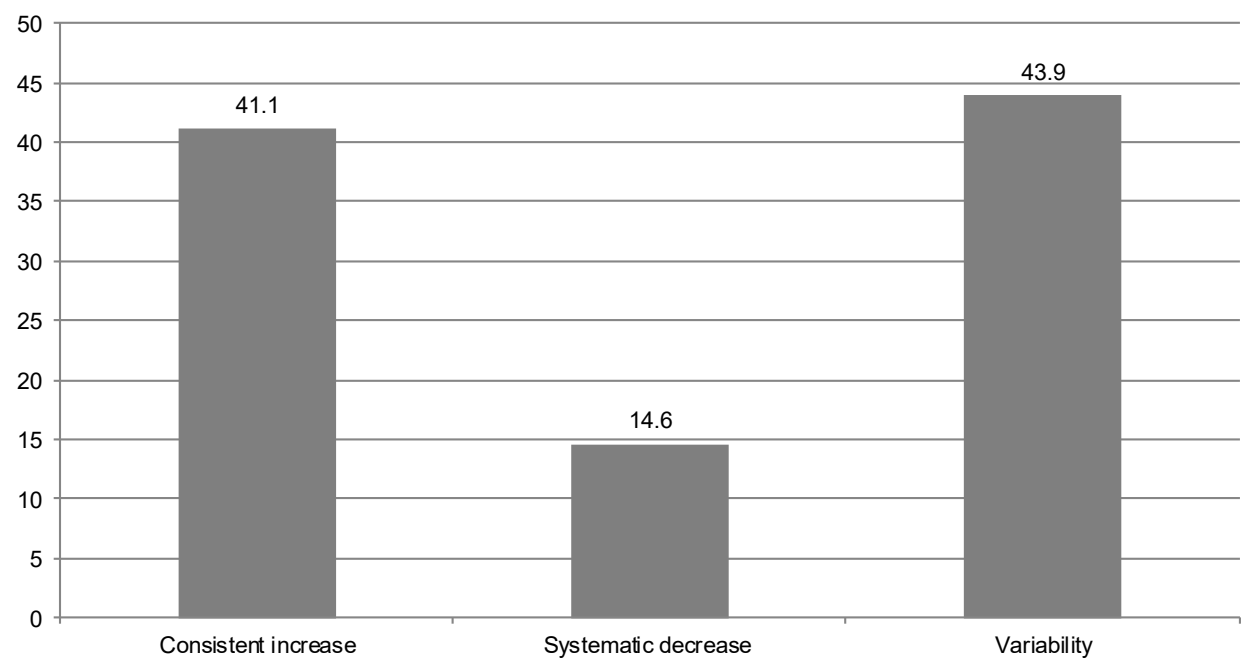

Figure 1. Determination of the trend in the municipality's budget expenditure on promotion from 2016 to 2018.

Communication activities of GZM municipalities using Facebook in relation to the structure of promotion expenditure.

\begin{tabular}{|c|c|c|c|c|c|}
\hline Municipality & Social coverage & $\begin{array}{c}\text { Number of inhabi- } \\
\operatorname{tants}^{\text {a) }}\end{array}$ & $\begin{array}{l}\text { Percentage } \\
\text { share }\end{array}$ & Promotional budget ${ }^{\mathrm{b}}$ & $\begin{array}{c}\text { Trend } \\
\mathrm{W} / \mathrm{S} / \mathrm{Z}^{\mathrm{c}}\end{array}$ \\
\hline 1 & 2 & 3 & 4 & 5 & 6 \\
\hline Będzin & 11380 & 57343 & 19.8 & 1163359.89 & W \\
\hline Bieruń & 4438 & 19639 & 22.5 & 342670.52 & S \\
\hline Bobrowniki & 3196 & 11921 & 26.8 & 128250.94 & $\mathrm{Z}$ \\
\hline Bojszowy & 1195 & 7795 & 15.3 & 65123.84 & $\mathrm{~W}$ \\
\hline Bytom & 20424 & 168394 & 12.1 & 192069.21 & S \\
\hline Chełm Śląski & 283 & 6245 & 4.5 & 78702.90 & $\mathrm{Z}$ \\
\hline Chorzów & 15402 & 109021 & 14.1 & 1589715.19 & $\mathrm{Z}$ \\
\hline Czeladź & 7587 & 31901 & 23.7 & 245543.57 & W \\
\hline Dąbrowa Górnicza & 18545 & 121121 & 15.3 & 7528876.40 & $\mathrm{Z}$ \\
\hline Gieraltowice & 479 & 12009 & 3.9 & 129475.31 & $\mathrm{Z}$ \\
\hline Gliwice & 31882 & 181309 & 17.5 & 7824466.88 & W \\
\hline Imielin & - & 9052 & - & 90043.69 & Z \\
\hline Katowice & 101627 & 296262 & 34.3 & 26265476.03 & W \\
\hline Knurów & 1962 & 38594 & 5.0 & 164789.59 & W \\
\hline Kobiór & - & 4898 & - & 11880.81 & $S$ \\
\hline Lędziny & 3262 & 16819 & 19.3 & 204617.49 & W \\
\hline
\end{tabular}




\begin{tabular}{|c|c|c|c|c|c|}
\hline 1 & 2 & 3 & 4 & 5 & 6 \\
\hline Laziska Górne & 3211 & 22390 & 14.3 & 119750.63 & Z \\
\hline Mierzęcice & - & 7691 & - & 36746.05 & Z \\
\hline Mikołów & 4168 & 40423 & 10.3 & 698959.61 & W \\
\hline Mysłowice & 8003 & 74647 & 10.7 & 679553.10 & $\mathrm{~S}$ \\
\hline Ożarowice & - & 5715 & - & 139878.93 & W \\
\hline Piekary Śląskie & 11202 & 55652 & 20.1 & 603839.19 & Z \\
\hline Pilchowice & 1543 & 11838 & 13.0 & 119139.43 & Z \\
\hline Psary & 1555 & 12046 & 12.9 & 175931.31 & $\mathrm{~S}$ \\
\hline Pyskowice & 4682 & 18417 & 25.4 & 161408.88 & W \\
\hline Radzionków & 4712 & 16798 & 28.0 & 223908.11 & Z \\
\hline Ruda Śląska & 17358 & 138578 & 12.5 & 815150.12 & W \\
\hline Rudziniec & 1493 & 10655 & 14.0 & 46798.66 & Z \\
\hline Siemianowice Śl. & 10677 & 67523 & 15.8 & 681574.30 & W \\
\hline Siewierz & 1847 & 12390 & 14.9 & 412823.56 & W \\
\hline Sławków & - & 7040 & - & 80308.09 & Z \\
\hline Sosnowiec & 21516 & 204013 & 10.5 & 946663.57 & W \\
\hline Sośnicowice & 1110 & 8821 & 12.5 & 230916.20 & Z \\
\hline Świerklaniec & 3000 & 12069 & 24.8 & 147373.98 & $\mathrm{Z}$ \\
\hline Świętochłowice & 3643 & 50385 & 7.2 & 596456.55 & $\mathrm{Z}$ \\
\hline Tarnowskie Góry & 16124 & 61262 & 26.3 & 1701220.00 & W \\
\hline Tychy & 17256 & 128211 & 13.4 & 1609496.00 & Z \\
\hline Wojkowice & 3172 & 8984 & 35.3 & 97193.52 & Z \\
\hline Wyry & 2244 & 8087 & 27.7 & 59967.38 & $\mathrm{~S}$ \\
\hline Zabrze & 13213 & 174349 & 7.5 & 1642402.51 & W \\
\hline Zbrosławice & 2201 & 16001 & 13.7 & 255292.43 & W \\
\hline
\end{tabular}

Table 1. Ratio of reaching recipients with the use of official accounts created by local government units forming GZM on Facebook.

a) Based on the Local Data Bank of the Central Statistical Office. State as of December 2016.

b) The data in PLN concerning the expenditure of municipalities in the area covered by the survey concern the year 2018 .

c) Determination of the trend in the municipality's budget expenditure on promotion: $\mathrm{W}$ - consistent increase from 2016 to 2018; S - systematic decrease in the surveyed period; Z - variability of expenditures in the years covered by the survey. 
Budget expenditure on the promotion of local government.

\begin{tabular}{|c|c|c|c|}
\hline Municipality & 2016 & 2017 & 2018 \\
\hline 1 & 2 & 3 & 4 \\
\hline Będzin & 819955.35 & 960094.70 & 1163359.89 \\
\hline Bieruń & 223096.85 & 274442.74 & 342670.52 \\
\hline Bobrowniki & 88158.89 & 53495.29 & 128250.94 \\
\hline Bojszowy & 36288.53 & 54058.24 & 65123.84 \\
\hline Bytom & 672929.91 & 353630.74 & 192069.21 \\
\hline Chełm Śląski & 29869.55 & 18013.48 & 78702.90 \\
\hline Chorzów & 3658208.76 & 1470924.33 & 1589715.19 \\
\hline Czeladź & $\begin{array}{c}\text { unseparated } \\
\text { section } 75075\end{array}$ & 222247.48 & 245543.57 \\
\hline Dąbrowa Górnicza & 7916868.93 & 8471745.57 & 7528876.40 \\
\hline Gieraltowice & 117202.96 & 195759.08 & 129475.31 \\
\hline Gliwice & 2749472.94 & 2445416.04 & 7824466.88 \\
\hline Imielin & 60910.50 & 60296.29 & 90043.69 \\
\hline Katowice & 17762991.65 & 20986223.87 & 26265476.03 \\
\hline Knurów & 108090.52 & 127424.82 & 164789.59 \\
\hline Kobiór & 12950.33 & 12098.25 & 11880.81 \\
\hline Lędziny & 122489.52 & 184393.45 & 204617.49 \\
\hline Laziska Górne & 135949.50 & 94434.79 & 119750.63 \\
\hline Mierzęcice & 25490.81 & 20772.76 & 36746.05 \\
\hline Mikołów & 481145.56 & 500582.16 & 698959.61 \\
\hline Mysłowice & 945998.33 & 722897.54 & 679553.10 \\
\hline Ożarowice & 74924.10 & 89347.24 & 139878.93 \\
\hline Piekary Śląskie & 504576.34 & 615057.05 & 603839.19 \\
\hline Pilchowice & 118486.67 & 95216.87 & 119139.43 \\
\hline Psary & 201366.26 & 190123.83 & 175931.31 \\
\hline Pyskowice & 109977.51 & 119717.23 & 161408.88 \\
\hline Radzionków & 260652.52 & 165682.04 & 223908.11 \\
\hline Ruda Śląska & 732163.17 & 801135.82 & 815150.12 \\
\hline Rudziniec & 56004.82 & 73828.75 & 46798.66 \\
\hline Siemianowice Śląskie & 536091.01 & 554509.77 & 681574.30 \\
\hline Siewierz & 232185.36 & 266922.60 & 412823.56 \\
\hline Slawków & 81074.56 & 60698.86 & 80308.09 \\
\hline Sosnowiec & 728447.40 & 811094.40 & 946663.57 \\
\hline Sośnicowice & 286357.65 & 173720.25 & 230916.20 \\
\hline
\end{tabular}




\begin{tabular}{|l|r|r|r|}
\hline \multicolumn{1}{|c|}{1} & 2 & 3 & \multicolumn{1}{c|}{4} \\
\hline Świerklaniec & 111395.16 & 258041.31 & 147373.98 \\
\hline Świętochlowice & 621862.81 & 894741.91 & 596456.55 \\
\hline Tarnowskie Góry & 1105092.00 & 1247377.00 & 1701220.00 \\
\hline Tychy & 703268.00 & 622635.00 & 1609496.00 \\
\hline Wojkowice & 103884.88 & 92960.09 & 97193.52 \\
\hline Wyry & 191446.02 & 68387.57 & 59967.38 \\
\hline Zabrze & 1248767.72 & 1412400.81 & 1642402.51 \\
\hline Zbrosławice & 240418.29 & 246680.54 & 255292.43 \\
\hline
\end{tabular}

Tables 2. The amount of expenditure on promotion in the years 2016-2018 in the municipalities currently making up the Upper Silesian- Zagłebie Metropolis (in PLN) is presented according to the budget classification in chapter 75075 .

\section{References}

Balicki J., Dryja P., Korłub W., Tyszka M. (2017), Metody i aplikacje zdalnego szkolenia mieszkańców inteligentnych miast, „Studia i Materiały Instytutu Transportu i Handlu Morskiego", no. 14.

Kidyba M., Makowski Ł. (2017), Samorzady wobec smart cities-wyzwania, „Chorzowskie Studia Polityczne", no. 13.

Kowalik K. (2018), Dialog, monolog, interakcja? Portal społecznościowy jako kanat komunikowania online samorzadu gminnego. Studium przypadku miasta Kielce, „Naukowy Przegląd Dziennikarski”, no.3.

Kowalik K. (2018), Media online samorzadów lokalnych - nowa struktura $w$ systemie medialnym. Próba ujęcia in statu nascendi, „Zeszyty Prasoznawcze”, no. 3.

Romanowski R. (2018), Szymkowiak A., Obecność samorzadów lokalnych w mediach społecznościowych w Polsce, „Zeszyty Naukowe. Organizacja i Zarządzanie. Politechnika Śląska", no. 129.

Szymkowiak A., Scheibe A. (2016), Komunikacja samorzadu terytorialnego ze społeczeństwem za pośrednictwem mediów społecznościowych, „Roczniki Kolegium Analiz Ekonomicznych SGH”, no. 40.

Directive 2016/2102 of the European Parliament and the Council (EU) of 26 October 2016 on the accessibility of websites and mobile applications of public sector bodies (OJ EU L $327 / 9$ of 2 December 2016).

Promulgation by the Prime Minister of 9 November 2017 on the announcement of the consolidated text of the Ministerial Council Regulation on the National Interoperability Framework, minimum requirements for public registers and exchange of information in electronic form and minimum requirements for ICT systems (Journal of Laws of 2017, item 2247). 
Act of 4 April 2019 on digital accessibility of websites and mobile applications of public entities (Journal of Laws of 2019, item 848).

Act of 8 March 1990 on Municipal Self-Government (Journal of Laws of 1990, item 95).

Act of 9 March 2017 on the Metropolitan Union in the Silesian Province (Journal of Laws of 2017, item 730).

Ordinance No. 19/2018 of the Sośnicowice Mayor, dated March 16th 2018, on establishing the procedure rules of the official fanpage of the Sośnicowice Municipality on the social networking site Facebook (BIP http://sosnicowice.i-gmina.pl).

Dariusz Krawczyk, Ph.D., member of the Polish Communication Association, member of the Committee on Organizational and Management Sciences of the Polish Academy of Sciences in Katowice, expert witness in social communication and management, Head of the Social Contacts Department in the City Hall in Zabrze 